\title{
Towards a renewed understanding of the complex nerves of the digital divide
}

\section{Farooq Mubarak}

Department of Information Systems Science

Turku School of Economics

University of Turku, Finland

\begin{abstract}
Past research has provided ample support for the assertion that advancement in Information and Communication Technologies (ICT) accelerates economic growth. Recently, developing countries are witnessing high growth rates in ICT; nevertheless, the pace of research in this sector is relatively lower than the developed world. Although the digital divide globally seems to be diminished over time, the awareness about the issue is on a continuous rise. Despite vast research in the field, the multidimensional aspects of the term 'digital divide' are poorly understood. The majority of the published literature on the digital divide suffers from the lack of a multidimensional perspective on the topic. It appears that the conventional knowledge base on the digital divide has caused confusion in academia rather than clarifications. The aim of this paper is to establish an adequate understanding of the enormous complexity that hides in the term 'digital divide'. For this purpose, a comprehensive literature review consisting of peer reviewed scientific articles was systematically conducted to understand and examine the current trends in the topic. Building on the past peer reviewed research; the present study discusses the multifaceted concept of the digital divide in depth and proposes future courses of action for policy makers.
\end{abstract}


Keywords: Digital divide, ICT, inclusion and exclusion, digital technologies, internet, economic growth

\section{Introduction}

\section{Purpose of the study and research questions}

The issue of the digital divide has grown in importance in light of recent global economic turmoil. A report published by International Telecommunications Union signifies the contribution of information and community technology (ICT) sector to world economic development (International Telecommunications Union, 2012). The past decade has seen the rapid development and diffusion of information technology in a number of developed countries (Drori \& Jang, 2003). However, such progress is remarkably low in developing countries (Chinn \& Fairlie, 2004, 1). Such uneven distribution of ICT leads to a level of inclusion and exclusion, where one group benefits from immediate availability of information and the other group suffers from lack of effective access to basic technological resources. This constitutes a divide labeled as 'digital divide', in academic terms. Much of the research work on the digital divide has originated from developed countries, and to date too little research attention has been paid to developing countries.

Although ICT represents a significant opportunity for world development, there is increasing concern that benefits shall be unevenly shared. This is in close accordance with the view of Rahim, Pawanteh and Salman (2011) who maintain that in terms of skills and usage, the digital divide is deepening and widening throughout the world. On one hand, developed countries propelled by latest ICT are consistently ascending stairs towards innovative success. On the other hand, the developing countries coupled with extreme poverty and ignorance, are lagging far behind in the digital race (Antonelli, 2003; Meng \& Li, 2002). Favorable government policies, strong economic structure, and high ICT diffusion rates, result in advanced digitalization patterns in developed countries. Those already at the doors of innovation in the developed world are far better in benefiting from ICT than those with limited computer skills in the developing and underdeveloped world.

Although over time the digital divide appears to be diminished with increasing penetration of ICT among world inhabitants, the awareness about the issue is 
continuously surging as witnessed by the growth of mounting literature on the topic. Almost 18 years have passed since the term 'digital divide' appeared on the surface; to date the developing world sees little respite from proceedings in ICT. Exponential growth of the internet worldwide indicates that the digital divide is being narrowed in terms of ICT penetration; however in absolute meanings, the digital divide appears to maintain its roots globally. It is a bitter fact that ICT diffusion follows a highly unequal distribution pattern throughout the world (Ya'u, 2005). Despite of the vivid significance that ICT entails, a surprising number of firms in developed economies have not adopted internet technology (Forman, 2005). While the digital divide in developed countries needs serious attention, the conditions in developing countries are even worse. Developing nations are often characterized as having increased inequality among the public in sources of income and disturbing political and cultural concerns, which directly influences their attitude towards ICT. Disparities among different segments of the population in effective access to digital technologies are causing an alarming digital inequality, thus constituting a wider social divide. As a result, the divide poses a massive threat towards the promises of globalization (Antonelli, 2003).

Beyond doubt, a considerable amount of literature has been published on the digital divide, particularly in the last decade. To date, most studies in the field of the digital divide have only focused on the technological access gap constituting the divide. Researchers have not treated significant issues (for example, infrastructure for ICT, cognitive skills of users, usability) of developing countries in much detail, yet all of those factors have profound impacts on the digital divide. Existing accounts have thus overlooked significant factors contributing towards widening of the digital divide locally and internationally. Hence, many controversies arise in the measurement of the digital divide (Corrocher \& Ordanini, 2002; Shade, 2002) as analysts continue to question the validity of input data. Moreover, many studies promulgate differential views towards the term 'digital divide', making it a confused theme in literature (Strover, 2003).

Academic research on the digital divide which is stimulated on speculations and biased promulgations achieves considerable criticism. The treatment of the digital divide offered by a number of researchers, while superficially attractive, is riddled with biases and inconsistencies leading to inappropriate recommendations for policymakers. This urges a pressing need to redefine the boundaries of the field. 
The aim of this paper is to attain a broad and adequate understanding of the digital divide by critically examining the prior research on the subject. The present study builds on past peer reviewed research in an attempt to understand the complex nerves of the digital divide. A comprehensive understanding of the digital divide and review of relevant progress constitute the major objective of this article. While prior research has mostly concentrated on threats of the digital divide, this paper gives a renewed understanding of the much confused term itself.

\section{Method}

\section{Research methodology employed}

Ginieis, Sánchez-Rebull and Campa-Planas (2012) note that the usefulness of a given study is its uptake rather than appearance in the print. Considering this, a dedicated context-sensitive research methodology is required to extract the most relevant publications on the topic of interest. The present literature on the digital divide seems to be methodologically diverse and seemingly contradictory. In line with the aim of this research, a systematic literature review approach was selected to produce an accurate and reliable knowledge base on the subject. In contrast to traditional literature reviews, systematic literature reviews are noted for their intensive coverage of the topic by accumulating data from a range of publications.

A systematic literature review is a comprehensive review of literature meant to identify, evaluate, and interpret the available research relevant to the phenomenon of interest (Kitchenham, 2004). Although systematic literature reviews do not involve strict experimentation, they do follow a standard framework and consistent applications of a method (Ginieis, Sánchez-Rebull, \& Campa-Planas, 2012). Systematic literature reviews can provide reasonable grounds to policy makers for formulating decisions by enhancing the legitimacy of the resultant evidence (Tranfield, Denyer \& Smart, 2003). Systematic literature reviews therefore, organize past research relevant to the topic and help in giving an overview of progress in the field. Systematic literature reviews have a key advantage over traditional reviews due to evidence based practices.

Performing the systematic literature review requires a series of discrete activities, which can be grouped into three main steps: planning, conducting, and reporting (Brereton, Kitchenham, Budgen, Turner, \& Khalil, 2007). The first phase is 
concerned with identifying the need of research into a particular area. This is followed by specifying the research purposes and a review protocol for a literature search through defined databases and other sources. A protocol entails the planning and process of how the literature review is conducted. The second phase deals with conducting the literature review where relevant research is identified and filtered according to defined inclusion and exclusion criteria. Finally, in the third phase, a report is written predicated on data from the preceding phases. Although strictly not required, the report may be validated through various quality appraisal tools.

\section{Scientific literature search strategy}

It was decided to conduct the literature search electronically due to vast possibilities of extracting the most relevant scientific publications online. The objective was to develop a most relevant, comprehensive and, reproducible search strategy capable of retrieving scholarly information on the digital divide in a wider scope. Keywords used in the search strategy were 'digital divide'. The language considered for the literature search was English. Table 1 shows the databases and search parameters used for conducting the literature search. All available publication years were chosen to ensure the consideration for a full scope of available literature.

Table 1

Identification of Databases and Fields Searched for Literature Retrieval

\begin{tabular}{l|l}
\hline Database & Fields searched in database \\
\hline ABI/INFORM Complete & All fields \\
EBSCO Host & All fields \\
Science Direct & All fields \\
\hline
\end{tabular}

\section{Selection criteria}

Peer reviewed scientific articles most relevant to the research theme were considered for this study. Abstracts, titles and conclusions of several articles and conference papers were reviewed, and those not fulfilling the inclusion criteria were excluded from the sample. If still in doubt, a whole article was thoroughly examined for ensuring relevancy to the subject. In doing so, references were saved, and reasons for exclusion were recorded. Relevant articles were marked, and all 
irrelevant articles were excluded from the collection. Combined results from all databases were electronically and manually filtered to determine if some publications were duplicates.

Table 2

Number of References Retrieved

\begin{tabular}{l|l}
\hline Source & Number of References \\
\hline References retrieved from electronic databases & 6236 (Abi inform) \\
$466 \quad$ (EBESCO) \\
$604 \quad$ (Science direct) \\
\hline Total references & 7306 \\
\hline
\end{tabular}

Articles were filtered systematically according to inclusion and exclusion criteria. 
Journal of Social Inclusion, 6(1), 2015

Table 3 shows the complete inclusion and exclusion criteria according to which the article selection was made. 
Table 3

Inclusion and Exclusion Criteria

\begin{tabular}{|c|c|c|}
\hline Factor & Inclusion Criteria & Exc/usion Criteria \\
\hline Source & $\begin{array}{l}\text { Scholarly article published } \\
\text { in peer-reviewed journal }\end{array}$ & $\begin{array}{l}\text { Article published in non- } \\
\text { peer reviewed media } \\
\text { such as newspapers, } \\
\text { trade journals, and } \\
\text { magazine articles }\end{array}$ \\
\hline Report Type & $\begin{array}{l}\text { Full-text articles } \\
\text { Original research } \\
\text { Systematic review }\end{array}$ & $\begin{array}{l}\text { Published abstracts, } \\
\text { published opinion letters, } \\
\text { review papers }\end{array}$ \\
\hline Language & English & All but English \\
\hline Publication Year & Any to date of search & N.A \\
\hline Duplication & N.A & Publication is a duplicate \\
\hline Content & $\begin{array}{l}\text { Content most relevant to the } \\
\text { understanding of digital } \\
\text { divide }\end{array}$ & $\begin{array}{l}\text { Digital divide issues } \\
\text { least addressed }\end{array}$ \\
\hline Nature of the studies & $\begin{array}{l}\text { Qualitative } \\
\text { Quantitative } \\
\text { Mixed method approach }\end{array}$ & N.A \\
\hline
\end{tabular}

\section{Structure of this article}

This article runs into four sections, including this ongoing introduction; while section 2 centers on the systematic literature review on the digital divide building on past peer-reviewed research. Following this, section 3 contains a thorough discussion on the findings and draws upon the entire article tying up various theoretical and empirical stands concerning the current state of the digital divide. Finally, section 4 represents conclusions reached from previous sections and proposes future lines of research into the subject.

\section{Results of literature filtering}

Table 4 shows the results of literature filtering. A large number of references were excluded at the title filtering stage. Following this, abstracts were read for the 
remaining articles, and 289 references marked for exclusion. In addition, twenty-one articles were completely examined; however, they did not fulfill the inclusion criteria. After the thorough literature filtering, 81 references were selected for the present study. Table 5 represents nature of the studies selected.

Table 4

Results of Literature Filtering

\begin{tabular}{l|l}
\hline Factors & $\begin{array}{l}\text { Number } \\
\text { References }\end{array}$ \\
\hline References prior to applying inclusion and & 7306 \\
exclusion criteria & \\
References excluded at title-filtering stage & 6915 \\
References excluded at abstract filtering stage & 289 \\
References excluded at full-text filtering stage & 21 \\
Total references excluded & 7225 \\
Total references included & 81 \\
\hline
\end{tabular}

Table 5 represents methods in the selected studies. A complete list of references that met the inclusion criterion at full text filtering stage is enclosed as Appendix 1 to this study.

Table 5

Methods of Studies Selected

\begin{tabular}{l|l}
\hline Nature of studies & Quantit \\
& $\boldsymbol{y}$ \\
\hline Qualitative & 48 \\
Quantitative & 20 \\
Mixed method approach & 13 \\
\hline
\end{tabular}




\section{Content analysis of the selected studies}

\section{The conceptual and early grounds of digital divide}

Information and communication technologies are revolutionizing the world economy (lyer, Taube, \& Raquet. 2002). High innovation rates and economic growth can be observed in the ICT-rich economies. The past decade has seen the rapid development of ICT in many sectors including education, business, and government. While the pace of development is stable in the western world, too slow progress is reported from many developing nations. With highly uneven distribution of ICT in their urban and rural settlements (Guillén \& Suárez, 2005), developing countries are missing out on significant opportunities of enhanced international trade and development.

Before the emergence of the digital divide concept in mid-1990s, general terms were used such as 'information' or 'knowledge gap', and 'computer literacy'. Although the exact origin of the term 'digital divide' is unknown, it is believed to have been popularized by Larry Irving, Assistant Secretary for Commerce in the Clinton administration (Tavani, 2003). Today, the digital divide seems to be a major development challenge as viewed across a range of academic scholars and policy makers. In the past two decades, a number of researchers have sought to determine 'digital divide' in its broad sense. As a result, various views are reported in literature presented in the forthcoming section.

\section{Contradicting views of the digital divide concept}

There is a considerable disagreement in the literature whether inequalities in access and use of digital technologies are increasing or decreasing among different demographic segments (Hargittai 2002). An empirical investigation found striking results which suggested that demographic factors have a marginal effect on the digital divide (Lee, 2010). The same view is documented by Katz, Rice and Aspden (2001) who maintain that concerning demographic factors such as age, gender, income, education, and race, the digital divide is shrinking. In their major exploratory study, Middleton and Chambers (2010) claim that digital inequalities are narrowing, but problems still persist. There is limitation to how far such claims can be taken. Viewed from the physical access perspective, digital inequalities appear to have narrowed over time. However, emerging ICT is disrupting the existing, and a new 
divide exists between individuals who benefit from the emerging ICT and those who do not.

Helbig, Ramon Gil-García and Ferro (2009) note that there is no clear consensus in the literature about the definition of the digital divide, and the term itself is often doubted for its appropriateness. A number of researchers (Dewan \& Riggins, 2005; Drouard, 2011; Hargittai, 2002; Menou 2001; Rye 2008) have defined the digital divide as a gap between people who have access to ICT and those who do not. A serious limitation with this definition is that it fails to take other factors such as attitude towards ICT and the feasibility of infrastructure into account. The same is noted by Ferro, Helbig, and Gil-Garcia (2011) who maintain that the traditional access-oriented definition of the digital divide is problematic as it tends to neglect the other variables such as IT-literacy and its influence on the digital divide. Hilbert (2011) maintains that the concept of the digital divide can be defined in terms far beyond the mere access to ICT. Thomas and Parayil (2008) conclude that the concept of the digital divide as merely an issue of access has been overstated. It follows that having access to ICT does not eliminate the problem, as the study by Li and Ranieri (2013) reminds us that participants equipped with ICT used the internet more for leisure activities than for education purposes.

From the arguments in the preceding paragraphs, it seems that the term digital divide encapsulates a deeper concept rather than a mere gap in access to ICT. Van Djik (2006) notes that the largest part of the digital divide research is based on divides concerning physical access to computers and calls for an urgent need to elaborate on conceptual aspects of the digital divide. This is in conjunction with the view of Al-Jaghoub and Westrup (2009) who assert that discussion on the digital divide needs to go beyond the statistics of physical connectivity to ICT.

However some researchers (Couldry, 2007; DiMaggio, Hargittai, Neuman, \& Robinson, 2001; Edwards, 2005; Fuchs \& Horak, 2008; Katz et al., 2001; Kyriakidou, Michalakelis, \& Sphicopoulos, 2011; Mordini et al., 2009; Moss, 2002; Noh \& Yoo, 2008; Tavani, 2003) have begun referring to the digital divide beyond the traditional access gap. For instance, Cullen (2001) refers to the digital divide as a gap between those who use ICT towards their benefit in daily lives and those who either are unable to benefit from technology or do not choose themselves to do so. Weiner, Puniello, Noland, Ciemnecki and Turakhia (2012) report that, over time, the concept of the digital divide has expanded to include the skills necessary to operate a 
computer and access the internet efficiently. More clearly, the digital divide is a separation between those who can efficiently access and utilize technology towards their benefit from those who cannot.

Van Djik (2006) identifies four different kinds of access namely: motivational access, material or physical access, skills access, and usage access. Van Djik further notes that the largest part of the digital divide research is based on divides concerning physical access to computers and the internet. However, in the recent years, terms such as 'beyond the digital divide', 'digital inclusion' and 'beyond the access' have been coined. This view is supported by a recent study (Bruno, Esposito, Genovese, \& Gwebo, 2011) which highlights that the notion of the digital divide is being increasingly considered as a multi-dimensional phenomenon rather than just a mere gap of access to ICT resources. Hence the digital divide ranges from individuals, communities and nations, to the global level. Chen and Wellman (2003) suggest using the term digital divide in plural form 'digital divides' as the nature of the digital divide varies among individuals, societies, and between countries.

\section{The digital divide as a multifaceted concept}

It bears emphasizing that the digital divide is multifaceted in nature. A growing body of literature has started to refer to the digital divide as a complex phenomenon (Chen, Lin, \& Lai, 2010). Ferro et al. (2011) provide considerable evidence that the digital divide is a complex phenomenon transcending simple information access issues. Hilbert (2011) states that the digital divide is a multi-dimensional phenomenon, and one size fits all definition shall be counterproductive. The digital divide goes far beyond mere socioeconomic and demographic factors. This view is supported by Busch (2011) who maintains that consequences of the digital divide reach far beyond mere access to telephones, computers, and the internet. Similarly, Klimaszewski and Nyce (2009) conclude that ICT success rates cannot be determined by the penetration rates of telephones and computers alone, rather actual gains should also be taken into account.

Mansell (2002) acknowledges that the digital divide is a multifaceted phenomenon which exists at many levels ranging from individual, societies, corporations, and regions to a global level. Indeed, the chief reason of the digital divide is varied distribution of ICT resources throughout the world (Doong \& Ho, 
2012). Studies such as that conducted by Beckman, Verma, and Mindel (2008) have shown that socio-economic status affects access patterns of ICT as individuals with high socio-economic status have greater access to ICT. However, phenomenon of the digital divide is beyond explanation solely on the basis of income disparities (Tavani, 2003). This follows that the digital divide is a complex topic which exists on several levels.

Even, developed countries face the challenge of universal access to internet connectivity in rural and remote areas (Klimaszewski \& Nyce, 2009). Thus, the digital divide has considerable roots in developed nations (Dijk \& Hacker, 2003). Research findings of Kyriakidou et al. (2011) indicate a stark difference in broadband adoption rates among European territories. In their major empirical examination, Vicente and López (2011) revealed that the digital divide across European regions continues to be huge despite massive financial efforts. This corroborates the research findings of Cruz-Jesus, Oliveira, and Bacao (2012), reporting a prevailing digital divide across Europe, even with increased financial initiatives. There are increasing concerns about the digital divide in developed nations along ethnic and gender lines (Rao 2005). For instance, Yong-Chan, Joo-Young and Ball-Rokeach (2007) report a significant digital divide in the United States based on ethnicity and suggest that policy makers should take ethic factor into consideration when devising policies to foster ICT.

Hindman (2000) reports a widening divide between urban and rural settlements with respect to usage of ICT. An empirical investigation (Schleife, 2010) identifies a regional digital divide where rural regions show lower ICT usage rates than urban settlements. Rao (2003) argues that despite access problems in urban areas, rural areas are the most to suffer from digital disparities in terms of ICT development, availability of electricity, and physical infrastructure. Cooke and Greenwood (2008) recognize the broad digital divide among workplaces, where job function limits workers who do and do not utilize ICT. Chen et al. (2010) note that the rural digital divide is serious in developing countries. Rural areas of developing countries are often without basic infrastructure, which self explains the corresponding digital divide. In comparison however, developed nations have higher rates of access and connectivity to computers and the internet.

Based on arguments in the preceding paragraph, it appears that the digital divide is in fact several divides. This does not necessarily rule 'access' as being the 
only factor contributing to the digital divide. Grubesic and Murray (2002) observed the disparities in broadband internet access based on geographically feasible factors and demonstrated that the digital divide is increasingly complex in nature. Among other factors, geographic area has been discovered as an important factor in understanding the digital divide (Cruz-Jesus et al. 2012). Scanlan (2008) demonstrated that the digital divide still exists regardless of equal access to technology among the studied population. Haythornwaite (2001) maintains that rather than access to ICT, usage differences among individuals need due research attention with respect to the digital divide.

\section{Measuring the digital divide}

Measurement of the digital divide has resulted in a number of published quantitative studies, among which some were conducted on a broad scale, (for instance, Billon, Lera-Lopez, \& Marco, 2010; Cruz-Jesus et al., 2012; Vicente \& López, 2011). However, accuracy of many quantitative studies has been questioned in the literature. Barzilai-Nahon (2006) claims that policy makers are inclined towards erroneous actions on the subject of the digital divide and calls for a comprehensive approach to measure the digital divide. Hargittai (2002) asserts that most government reports rely on the computer and internet usage factors to address the digital divide. Along similar lines, Billon, Marco and Lera-Lopez (2009) maintain that analyzing a single technology factor provides little information about the digitalization pattern of a country. Çilan, Bolat and Coşkun (2009) highlight the need for appropriate variables to measure the digital divide, given that prior studies have utilized unsatisfactory and varying variables to measure. Light (2001) maintains that there are vigorous debates about the magnitude of the digital divide due to varying research findings.

A recent study conducted by Billon et al. (2010) involves analyzing a sample of 142 developed and developing countries to determine the factors behind differential ICT adoption patterns. The experimental data are rather controversial, and there is no general agreement about reflection of accurate figures regarding ICT diffusion. Access to digital technologies without benefiting from them is considered in exclusion group with respect to the digital divide. Therefore, measurement of the digital divide should also consider other digital factors than only computer and internet access such as inequalities in mobile phones or digital television adoption. 
Bagchi (2005) notes that only a handful of empirical studies has dealt with the digital divide problem at a global level. Corrocher and Ordanini (2002) identify the inadequacy of previous research in measuring the digital divide and call for research into effectively addressing the digital divide issues on a global scale. James (2004) highlights the need for re-measuring the digital divide based on actual gainers of the internet rather than mere users. It is in this belief that there exists a massive difference between those who only surf the internet and those who surf and gain from the internet. In other words, there is a difference between just being connected to the internet and being connected with a dedicated purpose.

\section{Factors contributing to the digital divide}

Stok and Rider (2004) analyzed the publications of thirty leading researchers in the field of ICT and concluded that education, per capita/income, and age were principal casual factors underlying the digital divide. One major quantitative research (CruzJesus et al. 2012) aiming at analyzing the European digital divide across 27 countries reaches a striking conclusion, stating that school attendance does not have a significant impact on the digital divide. In their major study, Billon et al. (2010) found that Gross Domestic Product (GDP) and infrastructure as the main factors responsible for low digitalization in developing countries.

The digital divide reflects the high average levels of income in developed countries and relatively low in developing countries coupled with an equal distribution of income in the developed world and highly uneven in the developing world (Tipton, 2002). Individuals, especially women, in developing countries miss out on significant educational opportunities by working in farms to make ends meet (Olaniran \& Agnello, 2008). The emergent digital divide becomes self-evident. Quibria, Ahmed, Tschang, and Reyes-Macasaquit (2003) report a strong correlation between computer usage and GDP per capita. Brooks, Donovan and Rumble (2005) maintain that the cost of internet access in developing countries is considerably higher than in the developed world. Building on this line of research, it is clear that economic factors are a dominant cause of the digital divide between developed and the developing world.

Stanley (2003) identifies psychosocial resistance as a considerably strong factor responsible for the digital divide. A minor segment of the population might be resistant towards the use of a computer; however, this does not constitute a chief 
factor in addressing the issue of the digital divide. As an array of recent studies has reported, income factors still remain the dominant factors responsible for the present digital divide. However, it could be said that Stanley's argument relies too heavily on a qualitative analysis based on a limited number of hundred respondents. It seems that Stanley's interpretation overlooks a rising wave of computer literacy awareness in the global village, especially in the developing world.

Whilst it is generally agreed that income level and literacy are the dominant factors in explaining the digital inequality, the age factor remains largely ignored. McMurtrey, McGaughey and Downey (2008) identify older citizens as a profitable sector for ICT related services and point out that ICT companies are missing out on a serious stream of profits by ignoring them. Mordini et al. (2009) argue that older citizens are often precluded from using ICT, which could otherwise accrue towards their benefit, for instance to overcome isolation. However, ageing often accompanies disabilities which are a hindrance in achieving digital inclusion (Wright, 2010). Brodie et al. (2000) maintain that the ICT revolution with tremendous potential towards catering for healthcare needs is not reaching current retirees.

Gender plays an equally important role in understanding the digital divide. It is often perceived that women have considerably less interest towards ICT than men. Smith (2005) used a survey to determine the effect of gender on the digital divide and found that males acquired more computer skills than females. Contrary to Smith's findings, a recent study (Li \& Ranieri, 2013) found that there was no significant impact of gender on internet inequality issues; although the study reported that males were more likely to play games whereas females used the internet mostly for education purposes. Since both of these studies were conducted in different geographic territories, the changing role of gender towards technology due to cultural factors may be the reason behind opposite research findings.

Along with gender, cultural factors cannot be ignored either in the broad context of the digital divide. Klimaszewski and Nyce (2009) maintain that successful ICT implementation requires developers to take into account the cultural values and norms of the society. Brooks et al. (2005) note that a significant portion of the content on the internet is in English language, which acts as a barrier in most of the developing countries who have limited or no knowledge of English. Prieger and $\mathrm{Hu}$ (2008) found that cultural factors matter independently of demographic factors in the demand for broadband internet connections. 
Developing nations face severe crises beyond imagination that indirectly affect the digital divide. For instance, there is a considerable segment of world inhabitants which suffers from the absence of electricity, particularly in the poor regions. Rao (2003) mentions the case of Indian rural areas where the supply of electricity is limited to 6 to 8 hours a day often with inadequate voltage stability, which is outside the acceptable limits of ICT hardware. This is also echoed in the paper of Mansell (2002) who writes that lack of available and reliable electricity is an obstacle towards network connectivity in rural areas of the developing world. Moss (2002) points towards a severe global digital divide estimating that two billion people in the world are without electricity. Such energy crises would also move those individuals to the exclusion group who do have access to computers and internet, but suffer from frequent absence of electricity.

\section{Bridging the digital divide}

Bridging the digital divide seems easier said than done. This is in conjunction with the view of Cullen (2001) who writes that there are no quick fixes to the problem of the digital divide on a national or international level. DiBello (2005) argues that equity issues belonging to the digital divide are serious and cannot be solved overnight. There are a number of economic and social factors responsible for this difficulty. Most noteworthy are economic capital and government policies which are particularly true in the case of developing countries. Some studies speculate that market forces shall eventually reduce the digital divide (Fuchs \& Horak 2008).

Quibria et al. (2003) recommend that developing countries should place increased emphasis on education in order to benefit from new ICT opportunities. Swain and Pearson (2003) suggest that educational institutions can help reduce the digital divide after implementing technological standards. Similarly, Billon et al. (2009) suggest the adoption of ICT-based educational systems to overcome the digital divide. These suggestions seem valid mainly in developed countries, where educational institutions are supposedly equipped with technological resources. A small scale study (Sims, Vidgen, \& Powell, 2008) reaches different conclusions, finding no decrease in the digital divide with increasing use of electronic learning systems by universities. The study calls for an urgent attention of government to look deeper into the matter of the digital divide. 
A large scale study by Middleton and Chambers (2010) suggests that access to the high-speed internet might help in reducing the digital divide, particularly among enterprises. Similarly, Ganapati and Schoepp (2008) mention that provisions of wireless internet hold significant prospects towards the digital divide, particularly due to lower costs involved in wireless infrastructure. There needs to be however, a caution with these arguments as Vodoz, Reinhard and Giauque (2007) remind us that ensuring access to ICT is not sufficient to allow the efficient use of such technologies. The same view is documented by Dutton, Gillett, McKnight and Peltu (2004) who report the risk of ICT-access being overlooked by individual perceptions.

Noh and Yoo (2008) hold that ICT tends to reward those who know how to utilize it, and hence appropriate policies should focus on the elimination of barriers such as low levels of ICT skills, along with providing universal ICT access. Continuing in the same vein, Rao (2005) suggests two approaches to overcome the digital divide: one to enhance the usability skills of the public through policy initiatives, and second to design appropriate ICT-tools that are user friendly and do not require advanced computer skills.

Butcher (2009) draws attention towards spreading free open source software systems to reduce the digital divide, given that the information poor can be granted access to use and disseminate information. Despite its positive impact to some extent, one major drawback of this approach is that it overlooks the prime factors of the digital divide, given that psychological barriers, lack of skills, time and feasible infrastructure are prevalent, particularly in developing nations. Drouard (2011) encourages the policymakers to formulate action plans for increasing awareness among those who are on the wrong side of the digital divide, as a significant part of the excluded group often encounters motivational issues. It bears emphasizing that solutions to the digital divide should incorporate economical and infrastructural factors.

A number of previous studies (for instance, Çilan et al., 2009; Ferro et al., 2011; Helbig et al., 2009; Rao, 2005) have noted the importance of a government's role in reducing the digital divide. Pick and Azari (2008) examined 91 developed and developing countries and recommended several government initiatives for reducing the digital divide which include prioritizing education and promotion of foreign direct investment. This is in accordance with the view of (Yartey, 2008) that signifies the role of the financial sector for successful cross country diffusion of ICT. James 
(2008a) concludes that the digital divide shall not close rapidly without positive government intervention. A recent study (Chen et al., 2010) recognizes the increasing role of government and public institutions to bridge the digital divide, particularly in rural areas. Couldry (2007) calls for government recognition and action towards the surging risk of the digital divide. Basu and Chakraborty (2011) assert that governments need to invest towards making ICT inclusive among the public, in order to overcome the historical barriers of access.

Zhao, Kim, Suh, and Du (2007) conclude that the digital divide between developed and the developing world cannot be simply narrowed without cultivating competence in private firms within developing nations and through the supportive function of government. Hence, the role of governments and the corporate sector is equally important in reducing the global digital divide. This has also been documented by Mistry (2005) who recognizes the growing need of government and public institutions to play a productive role in spreading the benefits of ICT. For instance, James (2008b) notes that the internet has marginally penetrated in rural areas of developing countries; where the prodigious majority of poor are concentrated.

\section{Discussion}

Although, different kinds of divides have historically existed among generations on the accounts of resources and wealth, the digital divide in particular poses severe risks to the world economy. With increased ICT infrastructure, the majority of the citizens in developed countries have an instant access to sources of much information. They have thus competitive advantages over the developing world in the realm of innovation and trade. Without access to the entry in an electronic world, the majority of the residents in the developing world are deprived of sources of information, which might otherwise accrue to their benefits, economically and socially.

The current literature review advances an understanding of the digital divide as a complex and multidimensional phenomenon. When the term was first introduced in the mid-1990s, it was understood as a mere gap between the 'have' and 'have nots' regarding ICT. With the passage of time, research has uncovered various aspects of the digital divide, and the term is being understood as a complex 
and multi-dimensional phenomenon across a range of academic discourses. Much of the current debate revolves around the hazards of the digital divide and a variety of proposals to overcome the same. Although differences of opinion still exist, it is now widely accepted that the concept of the digital divide goes far beyond access to computers and internet.

The digital divide refers to disparities in effective access and utilization of ICT among different segments of societies on national and international levels. Thus, it can be argued that the concept of the digital divide centers on two main segments: efficient access to ICT and, efficient utilization of ICT. Figures of computer access can run into millions, corresponding benefits gained are a surprising question mark. Advocates of digital equality have already pointed towards perils of incrementing global economic inequality. Considering this, the digital divide is widening globally, posing severe risks to the world economy.

ICT is at the pulse of the innovation system particularly in the developed world which is ascending stairs towards market dominance. On the other hand, masses in developing countries that are on the margins of poverty, have limited or no access to basic ICT. Bearing in mind the previous points, it is necessary to accentuate that the digital divide is a widening risk without adequate action of governments. The divide has already threatened the employment situation in many countries including developed nations as a result of the constant rise in the demand of ICT skills. It follows that individuals on the wrong side of the divide are severely disadvantaged in their economic prospects.

The digital divide is evident both in developing and developed countries. Senior citizens are often among the exclusion group in the context of the digital divide. This ageing related digital divide is also referred to as 'grey digital divide'. Generally, senior citizens in developed countries have more assets, especially liquid assets as compared to younger citizens. As documented earlier in the literature review, ICT organizations are missing out on this remuneratively lucrative segment of society. The health care sector is an accurate example of how ICT can play its productive role in enhancing health care and extending it to underserved population. There is tremendous potential in this field which is worth dedicated investigation. The very prevalent clientele of ICT products and services are often of the young generation. Notably, shifting senior citizens from exclusion towards inclusion in regard to ICT should be of equal importance on the agenda of institutions. 
Although, a few quantitative studies aiming to measure the digital divide were conclusive at a high degree of confidence, nevertheless they did not escape criticism for data and methods employed. Some results are based on data from over 15 years ago and it is unclear if these differences still persist. Critics have also argued that not only do social surveys provide an inaccurate measure of the digital divide, but the reliability of available data from developing countries is questionable. Controversial data therefore, seriously impedes policy formulation and implementation to combat the digital divide. There appears to be no standard criterion to measure the absolute digital divide, although the relative digital divide can be measured to some extent based on ICT indicators.

Turning now to the question of bridging the digital divide, it is pertinent to mention that there is no immediate solution. It can be achieved through a steady process. Some authors suggest that market forces shall eventually lead towards narrowing the digital divide. It is naive to believe in such speculations that leave the digital divide at the mercy of market forces. Market forces shall reduce the price of ICT but continuously evolving latest ICT shall disrupt existing ones, thus the divide shall be reborn even if it is initially reduced. Similarly, others have speculated that providing access to ICT shall solve the digital divide. The problem appears to lie at government level where access to ICT is the issue, and on the individual level where usability is the issue. It follows that providing access to ICT is no guarantee that a user shall attain the intended benefit. Clearly, a mere donation of ICT does not seem to eliminate the digital divide.

Free open source software systems particularly in developing nations might be a partial solution to the digital divide. This might help bridging one part of a large digital divide, especially in the context where people with certain skills can use open source software. In developing countries free and open source software can play a productive part in education and computer literacy, provided that effective utilization is considered. What happens to individuals without computer efficacy and the supported infrastructure remains a question. A revolutionary approach is still needed that focuses on the multiple aspects of the digital divide.

Recently, a number of policy initiatives have been taken by governments of developed countries to promote ICT for boosting economic growth. For example, Nordic countries have seen a considerable uplift in ICT development. Conversely, poverty appears as a major obstacle, when it comes to similar efforts in developing 
countries. Among developing countries, there exists a large segment of the population which is living below the poverty line often without electricity and basic human needs, withstanding the vigorous tests of time. Here, the misfortune encounters humanity in its worst forms; the issue of the corresponding digital divide goes self-explanatory.

Investment in ICT, especially in developing countries might lead to new doors of international business opportunities, knowledge sharing, and economic growth. Many western advanced countries realized this long while ago, and presently are reaping such fruits. Despite tremendous business potential, developing countries face trade barriers due to lack of essential ICT. There is a rapidly growing literature on the digital divide, which indicates that the awareness about the issue is surging. There appears to be urgency for new processes and systems of governance to combat digital inequality; whereby, certain policy initiatives can be taken. This can be achieved through prioritizing ICT at a national level. Drawing upon the analysis and conclusions of previous research, it is possible to state that the threats posed by the surging digital divide shall continue, unless the governments intervene positively in their respective jurisdictions.

\section{Conclusion}

\section{Summary of findings}

The present study focused on extending the contemporary understanding of the digital divide by systematically analyzing the relevant peer reviewed literature. The digital divide is a wide and complex subject with multiple layers of content ranging from individual to country and global issues. The term embodies a deeper concept than mere inclusions and exclusions due to an ICT gap; instead, it breaks along a wide range of fronts including effective access, usability, and a variety of social and cultural variables. Digging deeper into the concept, the present study provides a renewed understanding of the multifaceted digital divide, uncovering various dimensions of the term, and including a discussion of its complexity and current trends.

The roots of the digital divide can be traced to mid-1990s when the term first appeared in a United States commerce report to represent a digital gap between entities with and without access to computers and the internet. The pace of research 
in this area has been stimulating ever since, resulting in a diverse and fragmented body of knowledge. To this day, the divide is persistent with its worst effects in developing nations. Although the said divide appears to be globally diminished with increased penetration of ICT, nevertheless the awareness about the issue is continuously surging.

At the very core of the digital divide, are the twin concepts of "efficient access to ICT" and "efficient utilization of ICT". Although the definitions of the 'digital divide' vary in their complexity, researchers alike agree that the divide is poisonous for global economic prosperity. Research has consistently shown the dangerous consequences of the digital divide on the world economy. The emergence of the digital divide as such gestures toward the discourse of the troubled global economy. On one hand a society in the developed world benefits from the easy and instant access to information; on the other hand a society in the developing world suffers from the absence of basic ICT infrastructure. Thus, ICT gains are mainly concentrated in wealthier economies, edging the poorer out of the field. However, the digital divide has victims both in developed and the developing world. Among developed countries, those having beneficial access to ICT have a competitive edge in terms of finding a good job, cheaper prices of goods, and health information over those who are without such access.

Developing countries, and among them especially the poorer territories hit by misfortune, are the most to suffer from the mars of the digital divide. Along with issues of hunger and ignorance, poverty also presents the digital divide to its respective recipients riddled with misfortune. It becomes self-explanatory that, for poverty ridden masses, the needs of access to ICT are pushed aside by basic human needs. Data from prior research suggests a high risk that the ICT revolution shall bypass rural segments of the developing nations. Extreme poverty, coupled with high illiteracy in rural areas of developing nations are the main roadblocks towards ICT integration. It is in this belief that profound impacts of the digital divide on national and the global economies are worth serious attention. It is a high time that governments attach importance to ICT diffusion in respective areas for a competitive society to play its part in the global village.

Senior citizens have been extensively ignored in literature on the question of analyzing the digital divide. No significant approaches have been geared towards seniors' inclusion in the realm of ICT. Ageing is already posing a threat to the 
economic system in western societies; it is crucial that increased importance should be attached to incorporate seniors in the issues of the digital divide. There is tremendous business potential in this sector which deserves due attention of ICT companies and policy makers. Adhering to increasing concerns voiced on the threats of senior citizens exclusion from ICT, it is imperative to develop policies and courses of actions to address the grey digital divide.

A number of studies have sought to quantify the digital divide in the past and current decade. However, questions have been raised about the accuracy and reliability of data being employed. Although much of the data sources are national surveys or personal observations, some variables are difficult to quantify such as individual attitude towards ICT. Different research approaches have used different variables while attempting to measure the digital divide, and hence varying results are reported in the literature. To this day, there is no standard framework for measuring the digital divide. Equally important to note is the fact that measurement of the digital divide yields relative divide, whereas an absolute digital divide still remains a challenge to be quantified, owing to the difficulties encountered in quantifying social variables.

The current study further emphasizes the recommendations of previous research which calls for the emerging role of government to combat the digital divide. The hypothesis at this point is that governments have sources and the power to exercise an ICT revolution in their respective areas. In such a context, particular attention is needed towards the masses in developing countries that are on the margins of poverty. It appears that reducing the global digital gap is a tough process without the strategic action on the part of governments and the public sector. Screams from champions of human rights and research are consistently highlighting the need for implementable policies to minimize the digital divide at a global level. The substance of the forgoing discourse implies that, unless governments take such issues seriously, the digital divide shall not only remain a threat but continue to surge in the coming periods of time.

\section{Limitations}

Finally, a number of important limitations need to be considered. The present study was not specifically designed to evaluate the factors related to the measurement of the digital divide. Albeit the present study has pointed towards language barrier 
contributing to the digital divide, it has not been discussed in detail. The study was based on 84 peer reviewed articles; however, as the debate sharpens, new theories are expected to emerge. Although, the present study has reached its aims, a review analysis could have studied various measurement mechanisms of the digital divide, which fell outside the boundaries of this paper due to a time barrier.

\section{Future directions}

The present study has thrown up many questions in need of future research. There is much to be said about an emerging role of government institutions towards narrowing the digital divide. It is suggested that before policy makers make financial decisions, studies similar to this one should be carried out on understanding the measurement mechanisms of the digital divide. An extension of this research could examine the emerging factors of the digital divide across different countries in further depth. The digital divide between developed and developing countries needs to be explored in a wide range of national and international contexts. In addition, research should develop a logical and standard framework of measuring the absolute digital divide.

Research is also needed to ensure the reliability of data for quantifying the digital divide, given that existing studies fail to represent accurate figures. There is considerable food for thought regarding ageing related to the digital divide. Owing to the lack of research on an ageing related digital divide (grey digital divide), researchers can be encouraged to dine on these issues. Rising inequalities in the access and use of ICT, and its adverse effects on national and the global economies should be a catalyst for future research into the digital divide. Issues such as cooperation between developed and developing countries over ICT are worthy topics of investigation for future research.

\section{References}

Antonelli, C. (2003). The digital divide: understanding the economics of new information and communication technology in the global economy. Information Economics and Policy, 15(2), 173-199.

Brereton, P., Kitchenham, B., Budgen, D., Turner, M., \& Khalil, M. (2007). Lessons from applying the systematic literature review process within the software engineering domain, Journal of Systems and Software, 80(4), 571-583. 
Chinn, D. \& Fairlie, W. (2004). The determinants of the global digital divide: A crosscountry analysis of computer and internet penetration, working paper, University of Wisconsin, Madison, WI, and National Bureau of Economic Research, Cambridge, MA.

Corrocher, N., \& Ordanini, A. (2002). Measuring the digital divide: A framework for the analysis of cross-country differences. Journal of Information Technology, 17(1), 9-19.

Drori, G., \& Jang, Y. (2003). The global digital divide - a sociological assessment of trends and causes. Social Science Computer Review, 21(2),144-161.

Forman, C. (2005). The corporate digital divide: Determinants of internet adoption. Management Science, 51(4), 641-654.

Ginieis, M., Sánchez-Rebull, M., \& Campa-Planas, F. (2012). The academic journal literature on air transport: Analysis using systematic literature review methodology. Journal of Air Transport Management, 19, 31-35.

International Telecommunications Union. (2012). Measuring the information society. Retrieved from http://www.itu.int/en/ITUD/Statistics/Documents/publications/mis2012/MIS2012 without Annex 4.pdf

Kitchenham, B. (2004). Procedures for performing systematic reviews. Keele University Technical Report TR/SE-0401\& NICTA Technical Report $0400011 T .1$.

Meng, Q., \& Li, M. (2002). New economy and ICT development in China. Information Economics and Policy, 14(2), 275-295.

Rahim, S. A., Pawanteh, L., \& Salman, A. (2011). Digital inclusion: The way forward for equality in a multiethnic society. Innovation Journal, 16(3), 1-12.

Shade, L. R. (2002). "The digital divide: From definitional stances to policy initiatives." Department of Canadian HeritageP3: Policy and Program Forum, Ottawa, 1-17.

Strover, S. (2003). Remapping the digital divide. The Information Society, 19, 275277.

Tranfield, D., Denyer, D., \& Smart, P. (2003). Towards a methodology for developing evidence-informed management knowledge by means of systematic review. British Journal of Management, 14(3), 207-222.

Ya'u, Y. Z. (2005). Globalisation, ICTs, and the new imperialism: Perspectives on Africa in the global electronic village. Africa Development, 30, 98-124.

\section{Biographical notes}

Farooq Mubarak is a doctoral candidate at Turku School of Economics in University of Turku, Finland. He completed his Master of Business Administration (M.B.A) degree in 2010 from Mohammad Ali Jinnah University, Karachi. Since his early childhood, he had an extreme and irresistible noble urge to acquire higher education from the West and learn the best principles of research. Despite poor circumstances, thankfully, his urge translated into reality for what had been a turning point in his life. It was due to GOD's blessing, the passion for research, and serious interest and hard work in the field of education. In the year 2010, he traveled to Finland in pursuit 
of an advanced Masters of Science (M.Sc.) degree in Economics and Business Administration. After completion, he started his doctoral studies in the same discipline and is currently a candidate for Doctor of Science (Dr.Sc.) in Economics and Business Administration. Author has previously written various articles and poems in general magazines and actively taken part in educational institution's own publication media. He has passion for research and has lived a dream of making an effective contribution to the scientific community through dedicated research on the digital divide and developing an excellent knowledge base for the coming generations. He holds a professional experience of approximately two years serving as a marketing manager in a private media organization in Karachi. He is inspired by beautiful nature on our planet and beyond, in the universe. His research themes include "conquering the digital divide", "ICT diffusion and global economy", and "Information Systems Science". wohi faroog@yahoo.com

Appendix 1 References that met the inclusion criterion at full text filtering stage

\begin{tabular}{|c|c|c|c|}
\hline Nr. & Full Reference & Database & $\begin{array}{l}\text { Nature of the } \\
\text { study }\end{array}$ \\
\hline 1. & $\begin{array}{l}\text { Al-Jaghoub, S., \& Westrup, C. (2009). Reassessing social } \\
\text { inclusion and digital divides. Journal of Information, } \\
\text { Communication \& Ethics in Society, 7(2), 146-158. }\end{array}$ & Abi/Inform & Qualitative \\
\hline 2. & $\begin{array}{l}\text { Bagchi, K. (2005). Factors contributing to global digital divide: } \\
\text { Some empirical results. Journal of Global Information } \\
\text { Technology Management, 8(3), 47-65. }\end{array}$ & Abi/Inform & Quantitative \\
\hline 3. & $\begin{array}{l}\text { Barzilai-Nahon, K. (2006). Gaps and bits: Conceptualizing } \\
\text { measurements for digital divide/s. Information Society, } \\
22(5), 269-278 .\end{array}$ & Ebsco & Qualitative \\
\hline 4. & $\begin{array}{l}\text { Basu, P., \& Chakraborty, J. (2011). New technologies, old } \\
\text { divides: linking internet access to social and locational } \\
\text { characteristics of US farms. GeoJournal, 76(5), 469- } \\
481 .\end{array}$ & Abi/Inform & Quantitative \\
\hline 5. & $\begin{array}{l}\text { Beckman, P., Verma, S., \& Mindel, J. (2008). The evolution of } \\
\text { large accidental wireless networks. JITTA : Journal of } \\
\text { Information Technology Theory and Application, 9(4), } \\
67-81 .\end{array}$ & Abi/Inform & Mixed method \\
\hline 6. & $\begin{array}{l}\text { Billon, M., Lera-Lopez, F., \& Marco, R. (2010). Differences in } \\
\text { digitalization levels: a multivariate analysis studying the } \\
\text { global digital divide. Review of World Economics, } \\
\text { 146(1), 39-73. }\end{array}$ & Ebsco & Quantitative \\
\hline 7. & $\begin{array}{l}\text { Billon, M., Marco, R., \& Lera-Lopez, F. (2009). Disparities in ICT } \\
\text { adoption: A multidimensional approach to study the } \\
\text { cross-country digital divide. Telecommunications Policy, } \\
\text { 33(10-11), 596-610. }\end{array}$ & $\begin{array}{l}\text { Science } \\
\text { direct }\end{array}$ & Quantitative \\
\hline
\end{tabular}




\begin{tabular}{|c|c|c|c|}
\hline 8. & $\begin{array}{l}\text { Brodie, M., Flournoy, R. E., Altman, D. E., Blendon, R. J., } \\
\text { Benson, J. M., \& Rosenbaum, M. D. (2000). Health } \\
\text { information, the internet, and the digital divide. Health } \\
\text { Affairs, } 19(6), 255-265 \text {. }\end{array}$ & Abi/Inform & Qualitative \\
\hline 9. & $\begin{array}{l}\text { Brooks, S., Donovan, P., \& Rumble, C. (2005). Developing } \\
\text { nations, the digital divide and research databases. } \\
\text { Serials Review, 31(4), 270-278. }\end{array}$ & $\begin{array}{l}\text { Science } \\
\text { direct }\end{array}$ & Qualitative \\
\hline 10. & $\begin{array}{l}\text { Bruno, G., Esposito, E., Genovese, A., \& Gwebu, K. L. (2011). } \\
\text { A critical analysis of current indexes for digital divide } \\
\text { measurement. Information Society, 27(1), 16-28. }\end{array}$ & Ebsco & Quantitative \\
\hline 11. & $\begin{array}{l}\text { Busch, T. (2011). Capabilities in, capabilities out: overcoming } \\
\text { digital divides by promoting corporate citizenship and } \\
\text { fair ICT. Ethics and Information Technology, 13(4), 339- } \\
\text { 353. }\end{array}$ & Abi/Inform & Qualitative \\
\hline 12. & $\begin{array}{c}\text { Butcher, M. P. (2009). At the foundations of information justice. } \\
\text { Ethics and Information Technology, 11(1), 57-69. }\end{array}$ & Abi/Inform & Qualitative \\
\hline 13. & $\begin{array}{l}\text { Chen, D., Lin, Z., \& Lai, F. (2010). Crossing the chasm - } \\
\text { understanding China's rural digital divide. Journal of } \\
\text { Global Information Technology Management, 13(2), 4- } \\
\text { 36. }\end{array}$ & Abi/Inform & Mixed method \\
\hline 14. & $\begin{array}{l}\text { Chen, W., \& Wellman, B. (2003). Charting and bridging digital } \\
\text { divides. I-Ways, 26(4), 155-161. }\end{array}$ & Ebsco & Qualitative \\
\hline 15. & $\begin{array}{l}\text { Çilan, Ç. A., Bolat, B. A., \& Coşkun, E. (2009). Analyzing digital } \\
\text { divide within and between member and candidate } \\
\text { countries o f European Union. Government Information } \\
\text { Quarterly, 26(1), 98-105. }\end{array}$ & $\begin{array}{l}\text { Science } \\
\text { direct }\end{array}$ & Quantitative \\
\hline 16. & $\begin{array}{l}\text { Cooke, L., \& Greenwood, H. (2008). "Cleaners don't need } \\
\text { computers": bridging the digital divide in the workplace. } \\
\text { Aslib Proceedings, } 60(2), 143-157 .\end{array}$ & Abi/Inform & Mixed method \\
\hline 17. & $\begin{array}{l}\text { Corrocher, N., \& Ordanini, A. (2002). Measuring the digital } \\
\text { divide: a framework for the analysis of cross-country } \\
\text { differences. Journal of Information Technology } \\
\text { (Routledge, Ltd.), 17(1), 9-19. }\end{array}$ & Ebsco & Qualitative \\
\hline 18. & $\begin{array}{l}\text { Couldry, N. (2007). New media for global citizens? The future of } \\
\text { the digital divide debate. The Brown Journal of World } \\
\text { Affairs, } 14(1), 249-261 .\end{array}$ & Abi/Inform & Qualitative \\
\hline 19. & $\begin{array}{l}\text { Cruz-Jesus, F., Oliveira, T., \& Bacao, F. (2012). Digital divide } \\
\text { across the European Union. Information \& } \\
\text { Management, 49(6), 278-291. }\end{array}$ & $\begin{array}{l}\text { Science } \\
\text { direct }\end{array}$ & Quantitative \\
\hline 20. & $\begin{array}{l}\text { Cullen, } \begin{array}{c}\text { R. (2001). Addressing the digital divide. Online } \\
\text { Information Review, 25(5), 311-320. }\end{array} \\
\end{array}$ & Abi/Inform & Qualitative \\
\hline 21. & $\begin{array}{l}\text { Dewan, S., \& Frederick, J. R. (2005). The digital divide: Current } \\
\text { and future research directions. Journal of the } \\
\text { Association for Information Systems, 6(12), 298-336. }\end{array}$ & Ebsco & Qualitative \\
\hline 22. & $\begin{array}{l}\text { Dibello, L. C. (2005). Issues in education: Are we addressing } \\
\text { the digital divide? Issues, access, and real commitment. } \\
\text { Childhood Education, } 81(4), 239-241 .\end{array}$ & Abi/Inform & Qualitative \\
\hline
\end{tabular}




\begin{tabular}{|c|c|c|c|}
\hline 23. & $\begin{array}{l}\text { Dijk, J. v., \& Hacker, K. (2003). The digital divide as a complex } \\
\text { and dynamic phenomenon. Information Society, 19(4), } \\
\text { 315-326. }\end{array}$ & $\begin{array}{l}\text { Science } \\
\text { direct }\end{array}$ & Qualitative \\
\hline 24. & $\begin{array}{l}\text { DiMaggio, P., Hargittai, E., Neuman, W. R., \& Robinson, J. P. } \\
\text { (2001). Social implications of the internet. Annual } \\
\text { Review of Sociology, 27, 307-336. }\end{array}$ & Abi/Inform & Qualitative \\
\hline 25. & $\begin{array}{l}\text { Doong, S. H., \& Ho, S.-C. (2012). The impact of ICT } \\
\text { development on the global digital divide. Electronic } \\
\text { Commerce Research and Applications. }\end{array}$ & $\begin{array}{l}\text { Science } \\
\text { direct }\end{array}$ & Quantitative \\
\hline 26. & $\begin{array}{l}\text { Drouard, J. (2011). Costs or gross benefits? - What mainly } \\
\text { drives cross-sectional variance in internet adoption. } \\
\text { Information Economics and Policy, 23(1), 127-140. }\end{array}$ & $\begin{array}{l}\text { Science } \\
\text { direct }\end{array}$ & Quantitative \\
\hline 27. & $\begin{array}{l}\text { Dutton, W. H., Sharon Eisner, G., McKnight, L. W., \& Peltu, M. } \\
\text { (2004). Bridging broadband Internet divides: } \\
\text { reconfiguring access to enhance communicative power. } \\
\text { Journal of Information Technology, 19(1), 28-38. }\end{array}$ & Abi/Inform & Qualitative \\
\hline 28. & $\begin{array}{l}\text { Edwards, Y. D. (2005). Looking beyond the digital divide. } \\
\text { Federal Communications Law Journal, 57(3), 585-592. }\end{array}$ & Abi/Inform & Qualitative \\
\hline 29. & $\begin{array}{l}\text { Ferro, E., Helbig, N. C., \& Gil-Garcia, J. R. (2011). The role of IT } \\
\text { literacy in defining digital divide policy needs. } \\
\text { Government Information Quarterly, 28(1), 3-10. }\end{array}$ & $\begin{array}{l}\text { Science } \\
\text { direct }\end{array}$ & Qualitative \\
\hline 30. & $\begin{array}{l}\text { Fuchs, C., \& Horak, E. (2008). Africa and the digital divide. } \\
\text { Telematics and Informatics, 25(2), 99-116. }\end{array}$ & $\begin{array}{l}\text { Science } \\
\text { direct }\end{array}$ & Mixed method \\
\hline 31. & $\begin{array}{l}\text { Ganapati, S., \& Schoepp, C. F. (2008). The wireless city. } \\
\text { International Journal of Electronic Government } \\
\text { Research, 4(4), 54-68. }\end{array}$ & Abi/Inform & Qualitative \\
\hline 32. & $\begin{array}{l}\text { Grubesic, T. H., \& Murray, A. T. (2002). Constructing the divide: } \\
\text { Spatial disparities in broadband access. Papers in } \\
\text { Regional Science, } 81(2), 197-221 .\end{array}$ & Ebsco & Mixed method \\
\hline 33. & $\begin{array}{l}\text { Guillén, M. F., \& Suárez, S. L. (2005). Explaining the global } \\
\text { digital divide: Economic, political and sociological } \\
\text { drivers of cross-national internet use. Social Forces } \\
\text { (University of North Carolina Press), 84(2), 681-708. }\end{array}$ & Ebsco & Mixed method \\
\hline 34. & $\begin{array}{l}\text { Hargittai, E. (2002). Second-level digital divide: Differences in } \\
\text { people's online skills. First Monday, 7(4). Retrieved } \\
\text { from http://firstmonday.org/article/view/942/864 }\end{array}$ & Ebsco & Qualitative \\
\hline 35. & $\begin{array}{c}\text { Haythornwaite, C. (2001). The internet in everyday life. The } \\
\text { American Behavioral Scientist, 45(3), 363-382. }\end{array}$ & Abi/Inform & Qualitative \\
\hline 36. & $\begin{array}{l}\text { Helbig, N., Ramón Gil-García, J., \& Ferro, E. (2009). } \\
\text { Understanding the complexity of electronic government: } \\
\text { Implications from the digital divide literature. } \\
\text { Government Information Quarterly, 26(1), 89-97. }\end{array}$ & $\begin{array}{l}\text { Science } \\
\text { direct }\end{array}$ & Qualitative \\
\hline 37. & $\begin{array}{l}\text { Hilbert, M. (2011). The end justifies the definition: The manifold } \\
\text { outlooks on the digital divide and their practical } \\
\text { usefulness for policy-making. Telecommunications } \\
\text { Policy, 35(8), 715-736. }\end{array}$ & $\begin{array}{l}\text { Science } \\
\text { direct }\end{array}$ & Qualitative \\
\hline
\end{tabular}




\begin{tabular}{|c|c|c|c|}
\hline 38. & $\begin{array}{l}\text { Hindman, D. B. (2000). The rural-urban digital divide. } \\
\text { Journalism and Mass Communication Quarterly, } 77(3), \\
\text { 549-560. }\end{array}$ & Abi/Inform & Quantitative \\
\hline 39. & $\begin{array}{l}\text { Iyer, L. S., Taube, L., \& Raquet, J. (2002). Global e-commerce: } \\
\text { rationale, digital divide, and strategies to bridge the } \\
\text { divide. Journal of Global Information Technology } \\
\text { Management, } 5(1), 43-68 .\end{array}$ & Abi/Inform & Qualitative \\
\hline 40. & $\begin{array}{l}\text { James, J. (2004). Reconstruing the digital divide from the } \\
\text { perspective of a large, poor, developing country. } \\
\text { Journal of Information Technology, 19(3), 172-177. }\end{array}$ & Abi/Inform & Qualitative \\
\hline 41. & $\begin{array}{c}\text { James, J. (2008a). Digital divide complacency: Misconceptions } \\
\text { and dangers. Information Society, 24(1), 54-61. }\end{array}$ & Ebsco & Qualitative \\
\hline 42. & $\begin{array}{l}\text { James, J. (2008b). The digital divide across all citizens of the } \\
\text { world: A new concept. Social Indicators Research, } \\
\text { 89(2), 275-282. }\end{array}$ & Ebsco & Qualitative \\
\hline 43. & $\begin{array}{l}\text { Katz, J. E., Rice, R. E., \& Aspden, P. (2001). The internet, } \\
\text { 1995-2000: Access, civic involvement, and social } \\
\text { interaction. The American Behavioral Scientist, 45(3), } \\
\text { 405-419. }\end{array}$ & Abi/Inform & Mixed method \\
\hline 44. & $\begin{array}{l}\text { Klimaszewski, C., \& Nyce, J. M. (2009). Does universal access } \\
\text { mean equitable access?: What an information } \\
\text { infrastructure study of a rural Romanian community can } \\
\text { tell us. New Library World, } 110(5 / 6), 219-236 \text {. }\end{array}$ & Abi/Inform & Qualitative \\
\hline 45. & $\begin{array}{l}\text { Kyriakidou, V., Michalakelis, C., \& Sphicopoulos, T. (2011). } \\
\text { Digital divide gap convergence in Europe. Technology } \\
\text { in Society, 33(3-4), 265-270. }\end{array}$ & $\begin{array}{l}\text { Science } \\
\text { direct }\end{array}$ & Quantitative \\
\hline 46. & $\begin{array}{l}\text { Lee, J. W. (2010). The roles of demographics on the } \\
\text { perceptions of electronic commerce adoption. Academy } \\
\text { of Marketing Studies Journal, 14(1), 71-89. }\end{array}$ & Abi/Inform & Quantitative \\
\hline 47. & $\begin{array}{l}\mathrm{Li}, \mathrm{Y} ., \text { \& Ranieri, M. (2013). Educational and social correlates of } \\
\text { the digital divide for rural and urban children: A study on } \\
\text { primary school students in a provincial city of China. } \\
\text { Computers \& Education, } 60(1), 197-209 .\end{array}$ & $\begin{array}{l}\text { Science } \\
\text { direct }\end{array}$ & Mixed method \\
\hline 48. & $\begin{array}{l}\text { Light, J. S. (2001). Rethinking the digital divide. Harvard } \\
\text { Educational Review, 71(4), 709-733. }\end{array}$ & Abi/Inform & Qualitative \\
\hline 49. & $\begin{array}{l}\text { Mansell, R. (2002). Constructing the knowledge base for } \\
\text { knowledge-driven development. Journal of Knowledge } \\
\text { Management, 6(4), 317-329. }\end{array}$ & Abi/Inform & Qualitative \\
\hline 50. & $\begin{array}{l}\text { McMurtrey, M. E., McGaughey, R. E., \& Downey, J. R. (2008). } \\
\text { Seniors and information technology: Are we shrinking } \\
\text { the digital divide? Journal of International Technology } \\
\text { and Information Management, 17(2), 121-136. }\end{array}$ & Abi/Inform & Qualitative \\
\hline 51. & $\begin{array}{l}\text { Menou, M. J. (2001). The global digital divide; beyond hiCTeria. } \\
\text { Aslib Proceedings, 53(4), 112-114. }\end{array}$ & Abi/Inform & Qualitative \\
\hline
\end{tabular}




\begin{tabular}{|c|c|c|c|}
\hline 52. & $\begin{array}{l}\text { Middleton, K. L., \& Chambers, V. (2010). Approaching digital } \\
\text { equity: is wifi the new leveler? Information Technology } \\
\text { \& People, 23(1), 4-22. }\end{array}$ & Abi/Inform & Quantitative \\
\hline 53. & $\begin{array}{l}\text { Mistry, J. J. (2005). A conceptual framework for the role of } \\
\text { government in bridging the digital divide. Journal of } \\
\text { Global Information Technology Management, 8(3), 28- } \\
\text { 46. }\end{array}$ & Abi/Inform & Qualitative \\
\hline 54. & $\begin{array}{l}\text { Mordini, E., Wright, D., Wadhwa, K., De Hert, P., Mantovani, E., } \\
\text { Thestrup, J., . . Vater, I. (2009). Senior citizens and } \\
\text { the ethics of e-inclusion. Ethics and Information } \\
\text { Technology, 11(3), 203-220. }\end{array}$ & Abi/Inform & Qualitative \\
\hline 55. & $\begin{array}{l}\text { Moss, J. (2002). 'Power and the digital divide'. Ethics and } \\
\text { Information Technology, 4(2), 159-164. }\end{array}$ & Abi/Inform & Qualitative \\
\hline 56. & $\begin{array}{l}\text { Noh, Y.-H., \& Yoo, K. (2008). Internet, inequality and growth. } \\
\text { Journal of Policy Modeling, 30(6), 1005-1016. }\end{array}$ & $\begin{array}{l}\text { Science } \\
\text { direct }\end{array}$ & Quantitative \\
\hline 57. & $\begin{array}{l}\text { Olaniran, B. A., \& Agnello, M. F. (2008). Globalization, } \\
\text { educational hegemony, and higher education. } \\
\text { Multicultural Education \& Technology Journal, 2(2), 68- } \\
\text { 86. }\end{array}$ & Abi/Inform & Qualitative \\
\hline 58. & $\begin{array}{l}\text { Pick, J. B., \& Azari, R. (2008). Global digital divide: Influence of } \\
\text { socioeconomic, governmental, and accessibility factors } \\
\text { on information technology. Information Technology for } \\
\text { Development, 14(2), 91-115. }\end{array}$ & Ebsco & Quantitative \\
\hline 59. & $\begin{array}{l}\text { Prieger, J. E., \& Hu, W.-M. (2008). The broadband digital divide } \\
\text { and the nexus of race, competition, and quality. } \\
\text { Information Economics and Policy, 20(2), 150-167. }\end{array}$ & $\begin{array}{l}\text { Science } \\
\text { direct }\end{array}$ & Quantitative \\
\hline 60. & $\begin{array}{l}\text { Quibria, M. G., Ahmed, S. N., Tschang, T., \& Reyes- } \\
\text { Macasaquit, M.-L. (2003). Digital divide: determinants } \\
\text { and policies with special reference to Asia. Journal of } \\
\text { Asian Economics, 13(6), 811-825. }\end{array}$ & $\begin{array}{l}\text { Science } \\
\text { direct }\end{array}$ & Mixed method \\
\hline 61. & $\begin{array}{l}\text { Rao, S. S. (2003). Information systems in Indian rural } \\
\text { communities. The Journal of Computer Information } \\
\text { Systems, 44(1), 48-56. }\end{array}$ & Abi/Inform & Qualitative \\
\hline 62. & $\begin{array}{l}\text { Rao, S. S. (2005). Bridging digital divide: Efforts in India. } \\
\text { Telematics and Informatics, 22(4), 361-375. }\end{array}$ & $\begin{array}{l}\text { Science } \\
\text { direct }\end{array}$ & Qualitative \\
\hline 63. & $\begin{array}{l}\text { Rye, S. A. (2008). Exploring the gap of the digital } \\
\text { divide: Conditions of connectivity and higher education } \\
\text { participation. GeoJournal, } 71(2-3), 171-184 \text {. }\end{array}$ & Abi/Inform & Qualitative \\
\hline 64. & $\begin{array}{c}\text { Scanlan, M. A. (2008). E-Commerce, race, and the digital } \\
\text { divide. Review of Business Research, } 8(4), 134-145 .\end{array}$ & Ebsco & Quantitative \\
\hline 65. & $\begin{array}{l}\text { Schleife, K. (2010). What really matters: Regional versus } \\
\text { individual determinants of the digital divide in Germany. } \\
\text { Research Policy, 39(1), 173-185. }\end{array}$ & $\begin{array}{l}\text { Science } \\
\text { direct }\end{array}$ & Quantitative \\
\hline 66. & $\begin{array}{l}\text { Sims, J., Vidgen, R., \& Powell, P. (2008). E-Learning and the } \\
\text { digital divide: Perpetuating cultural and socio-economic } \\
\text { elitism in higher education. Communications of the } \\
\text { Association for Information Systems, 22, 429-442. }\end{array}$ & Ebsco & Qualitative \\
\hline
\end{tabular}




\begin{tabular}{|c|c|c|c|}
\hline 67. & $\begin{array}{l}\text { Skok, W., \& Ryder, G. (2004). An evaluation of conventional } \\
\text { wisdom of the factors underlying the digital divide: a } \\
\text { case study of the Isle of Man. Strategic Change, 13(8), } \\
\text { 423-428. }\end{array}$ & Ebsco & Qualitative \\
\hline 68. & $\begin{array}{l}\text { Smith, S. M. (2005). The digital divide: Gender and racial } \\
\text { differences in information technology education. } \\
\text { Information Technology, Learning, and Performance } \\
\text { Journal, 23(1), 13-23. }\end{array}$ & Abi/Inform & Mixed method \\
\hline 69. & $\begin{array}{c}\text { Stanley, L. D. (2003). Beyond access: Psychosocial barriers to } \\
\text { computer literacy. Information Society, 19(5), 407-416. }\end{array}$ & Ebsco & Qualitative \\
\hline 70. & $\begin{array}{l}\text { Swain, C., \& Pearson, T. (2002). Educators and technology } \\
\text { standards: Influencing the digital divide. Journal of } \\
\text { Research on Technology in Education, 34(3), 326-335. }\end{array}$ & Ebsco & Qualitative \\
\hline 71. & $\begin{array}{l}\text { Tavani, H. T. (2003). Ethical reflections on the digital divide. } \\
\text { Journal of Information, Communication \& Ethics in } \\
\text { Society, 1(2), 99-108. }\end{array}$ & Abi/Inform & Qualitative \\
\hline 72. & $\begin{array}{l}\text { Thomas, J. J., \& Parayil, G. (2008). Bridging the social and } \\
\text { digital divides in Andhra Pradesh and Kerala: A } \\
\text { capabilities approach. Development \& Change, 39(3), } \\
\text { 409-435. }\end{array}$ & Ebsco & Qualitative \\
\hline 73. & $\begin{array}{l}\text { Tipton, F. B. (2002). Bridging the digital divide in Southeast } \\
\text { Asia. ASEAN Economic Bulletin, 19(1), 83-99. }\end{array}$ & Ebsco & Qualitative \\
\hline 74. & $\begin{array}{l}\text { van Dijk, J. A. G. M. (2006). Digital divide research, } \\
\text { achievements and shortcomings. Poetics, 34(4-5), 221- } \\
235 \text {. }\end{array}$ & $\begin{array}{l}\text { Science } \\
\text { direct }\end{array}$ & Qualitative \\
\hline 75. & $\begin{array}{l}\text { Weiner, M. D., Puniello, O. T., Noland, R. B., Ciemnecki, D., \& } \\
\text { Turakhia, C. (2012). Consider the non-adopter: } \\
\text { Developing a prediction model for the adoption of } \\
\text { household-level broadband access. Socio-Economic } \\
\text { Planning Sciences, } 46(3), 183-193 .\end{array}$ & $\begin{array}{l}\text { Science } \\
\text { direct }\end{array}$ & Mixed method \\
\hline 76. & $\begin{array}{l}\text { Vicente, M. R., \& López, A. J. (2011). Assessing the regional } \\
\text { digital divide across the European Union-27. } \\
\text { Telecommunications Policy, 35(3), 220-237. }\end{array}$ & $\begin{array}{l}\text { Science } \\
\text { direct }\end{array}$ & Mixed method \\
\hline 77. & $\begin{array}{l}\text { Vodoz, L., Reinhard, M., \& Giauque, B. P. (2007). The farmer, } \\
\text { the worker and the MP: The digital divide and territorial } \\
\text { paradoxes in Switzerland. GeoJournal, 68(1), 83-92. }\end{array}$ & Abi/Inform & Qualitative \\
\hline 78. & $\begin{array}{l}\text { Wright, D. (2010). Structuring stakeholder e-inclusion needs. } \\
\text { Journal of Information, Communication \& Ethics in } \\
\text { Society, 8(2), 178-205. }\end{array}$ & Abi/Inform & Qualitative \\
\hline 79. & $\begin{array}{l}\text { Yartey, C. A. (2008). Financial development, the structure of } \\
\text { capital markets, and the global digital divide. } \\
\text { Information Economics and Policy, 20(2), 208-227. }\end{array}$ & $\begin{array}{l}\text { Science } \\
\text { direct }\end{array}$ & Quantitative \\
\hline 80. & $\begin{array}{l}\text { Yong-Chan, K., Joo-Young, J., \& Ball-Rokeach, S. J. (2007). } \\
\text { Ethnicity, place, and communication technology: Effects } \\
\text { of ethnicity on multi-dimensional } r \\
\text { internet } \\
\text { connectedness. Information Technology \& People, } \\
\text { 20(3), 282-303. }\end{array}$ & Abi/Inform & Mixed method \\
\hline
\end{tabular}




\begin{tabular}{|c|c|c|c|}
\hline 81. & $\begin{array}{l}\text { Zhao, H., Kim, S., Suh, T., \& Du, J. (2007). Social institutional } \\
\text { explanations of global internet diffusion: A cross-country } \\
\text { analysis. Journal of Global Information Management, } \\
\text { 15(2), 28-29,35-55. }\end{array}$ & Abi/Inform & Quantitative \\
\hline
\end{tabular}

